\title{
The Role of Isopropyl Alcohol in the Properties of Sudanese Reformat Gasoline
}

\author{
MOHAMED EZELDIN ${ }^{1}$, ALI. M. MASAAD' \\ ABUALREISH. M.J.A ${ }^{1,2 *}$ and CHRISTINA YACOUB ISHAK ${ }^{3}$ \\ ${ }^{1}$ Department of Chemistry, Faculty of Science and Technology, Omdurman \\ Islamic University, Khartoum, Sudan. \\ ${ }^{2}$ Department of Chemistry, Faculty of Science, Northern Border University, \\ Arar, Kingdom of Saudi Arabia. \\ ${ }^{3}$ Department of Chemistry, Faculty of Science, University of Khartoum, Khartoum, Sudan. \\ ${ }^{*}$ Corresponding author E-mail: mustjeed_2008@ hotmail.com
}

http://dx.doi.org/10.13005/ojc/330458

(Received: June 20, 2016; Accepted: December 15, 2017)

\begin{abstract}
The role of isopropyl alcohol in the properties of Sudanese reformat gasoline (produced by the refinery located at Algily, Khartoum North city, in Sudan) was studied. The properties of the reformat gasoline which were investigated include, distillation, sulfur content, density, vapor pressure, oxidation stability, copper strip corrosion, gum existence, lead content, and the octane number. The addition of isopropyl alcohol (5 and 10\% (v/v)) improved the properties of the Sudanese reformat gasoline to the limits assigned by American Society For Testing And Materials (ASTM) and Khartoum refinery. The motor octane number (MON) of the reformat gasoline was determined initially by the Cooperative Fuels Research engine (CFR engine), MON was found to be 88.5. Results revealed that the addition of isopropyl alcohol 5 and $10 \%(\mathrm{v} / \mathrm{v})$ to the Sudanese reformat gasoline shift the value of the (MON) to 94.1 and 96 respectively.
\end{abstract}

Keywords: Isopropyl alcohol, Sudanese gasoline properties, Motor octane number, Cooperative fuels research engine.

\section{INTRODUCTION}

Additives and blending agents are added to the hydrocarbon mixture to improve the performance and stability of gasoline ${ }^{1}$ These compounds include anti-knock agents, anti-oxidants, metal deactivators, lead scavengers, anti-rust agents, anti-icing agents, upper-cylinder lubricants, detergents, and dyes ${ }^{2}$.Gasoline anti - knock additives are compounds which, when added to a gasoline fuel for spark ignition engines, raise its antiknock quality, which is expressed by octane numbers. The classes of compounds from which antiknock additives are selected include, Hydrocarbons of natural high octane number, aromatic amines and organo metallic compounds $^{3}$ 
Other methods used to improve the quality of gasoline and increase its supply include polymerization, alkylation, isomerization, and reforming, using either heat or a catalyst to rearrange the molecular structure ${ }^{4,5}$.

Environmental friendly additives such as diethylamine, di isopropyl ether, moringa oil, acetone and many others are gasoline soluble chemicals that mixe with reformat gasoline to enhance octane number of gasoline, witch Ezeldin et al., found that the addition of aniline and toluene improved the quality of Sudanese reformat gasoline through increasing its motor octane number (MON) (initially 88.5) to 93.8 and 95.5 in addition of aniline (5 and $10 \%(\mathrm{v} / \mathrm{v}))$ and to 91 and 94.2 in addition of toluene (5 and 10\% (v/v)). Ezeldin et al., also found that when dimethylamine was added with different concentrations (5 and $10 \%(\mathrm{v} / \mathrm{v})$ ) to the Sudanese reformat gasoline the (MON) raised from 88.5 to 92.5 and 94.9 , respectively $6,7,8,9$. Typically, they are derived from petroleum based raw materials and there.

\section{MATERIALS AND METHODS}

All chemicals used were of pure analytical reagent grade $(A R)$. All solutions were prepared according to the usual analytical procedures.

Standard test methods, for the evaluation of distillation, density, vapour pressure, gum content, copper strip corrosion, oxidation stability, sulfur content and motor octane number reading in CFR engine were carried out according to the ASTM D 86, 1293, 323, 381, 93,514, 2624 and 2900 respectively ${ }^{10}$. Results are listed below in Table (1)

\section{Determination of lead concentration in gasoline by atomic absorption spectrophotometer method}

Preparation of sample

In a $100 \mathrm{~mL}$ volumetric flask $30 \mathrm{~mL}$ of methyl isobutyle ketone and $5 \mathrm{~mL}$ of a buffer solution $\mathrm{pH}=10$ were taken, then $0.1 \mathrm{~g}$ of iodine and $5 \mathrm{~mL}$ of gasoline were transferred to the solution, finely the solution was completed to the mark with methyl isobutyl ketone ${ }^{11}$.
Preparation of the standard lead (II) solution

A $0.5,1.0$ and 2.0 ppm of lead (II) solutions were prepared by dissolving known weight of $\mathrm{Pb}$ (II) in known volume of deionized water.

\section{Blank of the instrument}

The device was blanked with deionized water and then the sample was injected into the device where a process of atomization of lead in gasoline takes place (in the path of the light from the bulb short)and the device read the amount of lead directly ${ }^{12}$. Results are shown in table (1).

The effect of adding different concentrations of isopropyl alcohol to Sudanese reformate gasoline

Isopropyl alcohol as additive is gasoline soluble chemicals which mixed with reformat gasoline to enhance its octane number. iso propyl alcohol was added to the reformat gasoline at different concentrations $5 \%$ and $10 \%(\mathrm{v} / \mathrm{v})$ as follow:

- A $1000 \mathrm{ml}$ of reformat gasoline was prepared at refrigerator temp. and transferred to glass container had fitting cover.

The octane number of gasoline was measured by CFR engine, and all physicochemical properties of gasoline were also detected before the addition of acetone.

- $\quad$ Two glass container were filled with $1000 \mathrm{ml}$ of reformat gasoline and by using a pipette iso propyl alcohol was added in different concentrations $5 \%$ and $10 \%(\mathrm{v} / \mathrm{v})$ with shaking .

The octane number of these blends was measured by CFR engine, and all physicochemical properties were also detected after the addition of isopropyl alcohol. Results are shown in table (1).

\section{RESULTS AND DISCUSSION}

From the table 1 it is obvious that, the distillation test of reformat gasoline before and after treatment showed a decrease in the final boiling points (FBP), which give a strong evidence, that the quality of the reformat gasoline has improved after two additions of $(5,10 \% \mathrm{v} / \mathrm{v})$ of isopropyl 
alcohol. Also, the Initial Boiling Points (IBP) of the same reformat gasoline sample after treatment were decreased; this may be attributed to the conversion of some liquid petroleum gas (LPG) into fuel ${ }^{13}$.

The decrease in the initial boiling points (IBP) after all additions also indicated that, the quality of gasoline was improved.

The addition of isopropyl alcohol with different concentrations raises the value of the octane number after the distillation and refining processes. Therefore, the distillation test gives an interpretation about the raising or lowering of the octane number ${ }^{10}$. No limits had been assigned for the density and vapor pressure by ASTM, because they depend to a greater extent on the temperature of the country, but the refineries has assigned limits to these physical parameters as shown in table (2).

According to the limits assigned for the density and vapor pressure, the results obtained in table (1)., appears to be in permissible range.
The percent of gum in gasoline affect on its stability, which can be a (+ve) or (-ve) effect on the octane number and the quality of the gasoline.

The gum existence after first addition being stable at $(0.8 \mathrm{mg} / 100 \mathrm{ml})$ and after the second addition increased to $0.95 \mathrm{mg} / 100 \mathrm{ml}$ and these results appears to be in permissible range assigned by ASTM as shown in table (3).

Copper corrosion may take place in the gasoline tank or the engine that use gasoline, so the test of the copper strip corrosion is very important to be carried out ${ }^{14}$.

ASTM stablished a color table from which it is possible to determine if corrosion of a copper plate when immersed in a gasoline sample takes place or not by comparison with ASTM copper strip corrosion standard. It is obvious that the result (1a) obtained after both additions is within permissible limits which indicates good quality of the Sudanese reformate gasoline.

Table 1: Some physicochemical properties of Sudanese reformat gasoline before and after addition of iso propyl alcohol

\begin{tabular}{|c|c|c|c|c|c|}
\hline \multirow{6}{*}{$\begin{array}{l}\text { Test name } \\
\text { Distillation }\end{array}$} & \multicolumn{2}{|c|}{$\begin{array}{l}\text { Reformat Gasoline } \\
\text { (R.G) before } \\
\text { addition of } \\
\text { iso propyl alcohol }\end{array}$} & \multicolumn{2}{|c|}{$\begin{array}{l}1000 \mathrm{ml} . R \cdot G+ \\
50 \mathrm{ml} \text { iso } \\
\text { propyl alcohol }\end{array}$} & $\begin{array}{l}1000 \mathrm{ml} . R \cdot G+ \\
100 \mathrm{ml} \text { iso } \\
\text { propyl alcohol }\end{array}$ \\
\hline & $\begin{array}{l}\text { Initial Boiling } \\
\text { Point (IBP) }\end{array}$ & $37.9^{\circ} \mathrm{C}$ & $\begin{array}{l}\text { Initial Boiling } \\
\text { Point (IBP) }\end{array}$ & $36.5^{\circ} \mathrm{C}$ & $\begin{array}{l}\text { Initial Boiling } 33.7^{\circ} \mathrm{C} \\
\text { Point (IBP) }\end{array}$ \\
\hline & $10 \%$ & $58.5^{\circ} \mathrm{C}$ & $10 \%$ & $57^{\circ} \mathrm{C}$ & $10 \% \quad 55.6^{\circ} \mathrm{C}$ \\
\hline & $50 \%$ & $97.2^{\circ} \mathrm{C}$ & $50 \%$ & $95^{\circ} \mathrm{C}$ & $93.5^{\circ} \mathrm{C}$ \\
\hline & $90 \%$ & $159.0^{\circ} \mathrm{C}$ & $90 \%$ & $157.2^{\circ} \mathrm{C}$ & $90 \% \quad 157.6^{\circ} \mathrm{C}$ \\
\hline & $\begin{array}{l}\text { Final Boiling } \\
\text { Point (FBP) }\end{array}$ & $190.5^{\circ} \mathrm{C}$ & $\begin{array}{l}\text { Final Boiling } \\
\text { Point (FBP) }\end{array}$ & $185.2^{\circ} \mathrm{C}$ & $\begin{array}{l}\text { Final Boiling } 182.1^{\circ} \mathrm{C} \\
\text { Point (FBP) }\end{array}$ \\
\hline Density & \multicolumn{2}{|c|}{$736.4 \mathrm{k} / \mathrm{m}^{3}\left(150^{\circ} \mathrm{C}\right)$} & \multicolumn{2}{|c|}{$729 \mathrm{k} / \mathrm{m}^{3}\left(150^{\circ} \mathrm{C}\right)$} & $701 \mathrm{k} / \mathrm{m}^{3}\left(150^{\circ} \mathrm{C}\right)$ \\
\hline Vapor pressure & \multicolumn{2}{|c|}{$52.5 \mathrm{KPa}\left(37.8^{\circ} \mathrm{C}\right)$} & \multicolumn{2}{|c|}{$49 \mathrm{KPa}\left(37.8^{\circ} \mathrm{C}\right)$} & $49.1 \mathrm{KPa}\left(37.8^{\circ} \mathrm{C}\right)$ \\
\hline Gum content & \multicolumn{2}{|c|}{$0.8 \mathrm{mg} / 100 \mathrm{ml}$} & \multicolumn{2}{|c|}{$0.8 \mathrm{mg} / 100 \mathrm{ml}$} & $0.95 \mathrm{mg} / 100 \mathrm{ml}$ \\
\hline Copper corrosion & \multicolumn{2}{|l|}{$1 \mathrm{a}$} & \multicolumn{2}{|l|}{$1 \mathrm{a}$} & $1 \mathrm{a}$ \\
\hline Lead percentage & \multicolumn{2}{|l|}{$0.001 \mathrm{mg} / \mathrm{L}$} & \multicolumn{2}{|l|}{$0.001 \mathrm{mg} / \mathrm{L}$} & $0.001 \mathrm{mg} / \mathrm{L}$ \\
\hline Oxidation stability & \multicolumn{2}{|l|}{$494 \min$} & \multicolumn{2}{|l|}{$452 \min$} & $403 \mathrm{~min}$ \\
\hline Sulfur percentage & \multicolumn{2}{|l|}{$58.49 \mathrm{mg} / \mathrm{L}$} & \multicolumn{2}{|l|}{$58.49 \mathrm{mg} / \mathrm{L}$} & $58.49 \mathrm{mg} / \mathrm{L}$ \\
\hline $\begin{array}{l}\text { Pressure reading } \\
\text { in CFR engine }\end{array}$ & \multicolumn{2}{|l|}{$0.583 \mathrm{KPa}$} & \multicolumn{2}{|l|}{$0.502 \mathrm{KPa}$} & $0.475 \mathrm{KPa}$ \\
\hline $\begin{array}{l}\text { Motor octane } \\
\text { number }\end{array}$ & \multicolumn{2}{|l|}{88.5} & \multicolumn{2}{|l|}{94.1} & 96 \\
\hline
\end{tabular}




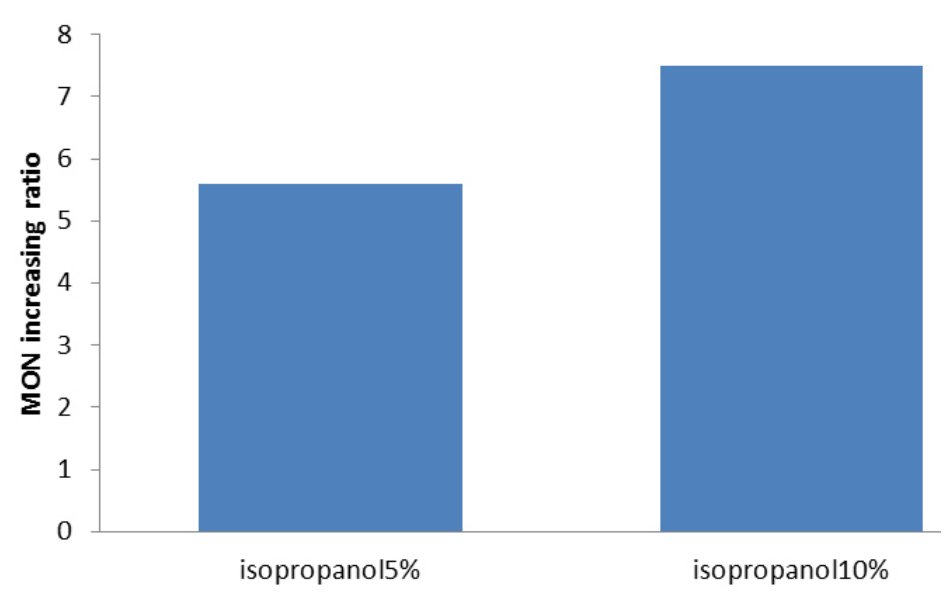

Fig. 1: Effect of isopropyl alcohol concentration on the value of MON

Table 2: Limits of physical parameters gasoline assigned by Khartoum refinery

\begin{tabular}{lcc}
\hline Test & Summer & Winter \\
\hline Density & $>740 \mathrm{~kg} / \mathrm{m}^{3}$ & $>740 \mathrm{~kg} / \mathrm{m}^{3}$ \\
Vapour pressure & $40-67 \mathrm{KPa}$ & $40-85 \mathrm{KPa}$ \\
\hline
\end{tabular}

Table 3: The permissible range assigned by ASTM

\begin{tabular}{lll}
\hline Test name & Permissible range & ASTM \\
\hline Distillation & $\mathrm{FBP} \leq 250^{\circ} \mathrm{C}$ & $\mathrm{D} 86-99 \mathrm{a}$ \\
Gum content & $0.5-2 \mathrm{mg} / 100 \mathrm{ml}$ & $\mathrm{D} 381-99$ \\
Copper corrosion & $1 \mathrm{a}$ or $1 \mathrm{~b}$ & $\mathrm{D} 183-91$ \\
Oxidation stability & $>240 \mathrm{mints}$ & $\mathrm{D} 525-99 \mathrm{a}$ \\
Sulfur content & $>250 \mathrm{ppm}$ & $\mathrm{D} 4294-89$ \\
Lead content & $>0.001 \mathrm{ppm}$ & $\mathrm{D} 3341-91$ \\
\hline
\end{tabular}

The lead content of the reformat gasoline before any addition of iso propyl alcohol was found to be $(0.001 \mathrm{mg} / \mathrm{L})$ which it is within the permissible limits assigned by ASTM, this value was not altered after both additions of iso propyl alcohol. Oxidation stability considered as one of the most important property that used to assess the quality of gasoline, since it give clue on the circumstances of the product storing, and also the heat required to start the combustion of gasoline inside the engine. Results obtained from the oxidation stability test also lies within the permissible range of ASTM as shown in table (3).
When adding isopropyl alcohol 5 and 10\% $(\mathrm{v} / \mathrm{v})$ it was observed that the Sulfur percentage was stable and results obtained from sulfur content test was fond within the right permissible range assigned by ASTM, this means a high quality was occurred because high sulfur percentage ( $\geq 250 \mathrm{ppm}$ ) causes corrosion and lowers the octane number.

Figure (1) shows the effect of adding isopropyl alcohol at different concentrations to the Sudanese reformat gasoline. The increase in the value of the motor octane number of the Sudanese reformat gasoline from 88.5 initially to 94.1 and 96 by the addition of 5 and $10 \%(\mathrm{v} / \mathrm{v})$ isopropyl alcohol respectively, indicates that isopropyl alcohol improve the quality of the Sudanese reformat gasoline, this improvement is attributed to the ability of the material to convert the hydrocarbon chains into cyclic compounds or increasing the branched chains in gasoline. .

\section{CONCLUSION}

Motor Octane Number (MON) of reformat gasoline used in this project before improvement process was found to be 88.5 .

Isopropyl alcohol showed different abilities in improving MON of reformat gasoline produced at Khartoum Refinery.

The density and vapour pressure properties for reformat gasoline after additions with different 
concentration were found to be within the range assigned by Khartoum refinery.

Other properties for reformat gasoline after all additions with different concentration were found within the limits assigned by ASTM.
MON was improved to $94.1 \& 96$ after adding isopropyl alcohol $5 \& 10(\mathrm{v} / \mathrm{v})$ respectively.

\section{REFERENCES}

1. Meusinger, R., Morose, R. "Determination of quality structure - octane rating relationship of hydrocarbons by genetic algorithms". Chem. Intell. Lab. Syst., 1999. 46(3), 412 425.

2. Perdiha, A., perdiha F, "Chemical interpretation of octane number".Acta. chem. Solv. 2006. (53) 315-360.

3. Meusing, R ., Morose,R. " Determination of octane numbers of gasoline compounds from their chemical structure by $13 \mathrm{CNMR}$ spectroscopy and neural net work". Petroleum product research, 2001, 80, 613-630.

4. Domask, W, G.." Introduction to petroleum hydrocarbons chemistry and commission in relation to petroleum derived fuels and solvent". New York : Van Nostr and Reinhold Company, 2000.

5. Devold, H." Introduction to oil and gas production" (3rd ed). Oslo :ABB ATPA oil and gas, 2006.

6. Lago, H, J., et al. "Correlation between octane number and catalytic cracking naphtha composition".Ind. Eng. Res., 1999. 38(6), 2171- 2190

7. Moh.Ezeldin, Ali.M.Masaad, Abualreish, M.J.A"Quality improvement of reformat gasoline by using aniline and toluene", International Journal of Current Research, 2015, 7, (9), 20531-20538.
8. Moh Ezeldin, Ali . M. Masaad, M. J. A Abualreish ,Sulieman A. G. Nasir1 and A. Omer Goda" Effect of Dimethyl Amine on Physicochemical Properties of Reformat Gasoline"Academia Journal of Scientific Research, 2015, 3(9), 131-141.

9. Ezeldin,M., Massad, A. "Quality improvement of Sudanese gasoline by using di isopropyl ether and moringa oil". European Academic Research, 2015, 3(3),2748 - 2763.

10. Ezeldin, M., Masaad ,A, M., Abualreish, M. J.A., Osama, A. "Physico-chemical Properties ofBlended Gasoline Samples produced from Khartoum Refinery in Sudan. "Research Journal of Chemistry and Environment, 2015, 19(11), 22- 31.

11. Kerr, S., Sarede, D. The united state lead phase down. U.S. EPA : University of Maryland, 1997.

12. Gibbs, L, M., Bonazza, B,R. "Distillation and vapourpressure" (8th ed). West Conshohohochen :Salvter. J. Rand. 2008.

13. Twu, C, H., Rogone,G. "Estimate octane numbers using and enhanced method. "Hydrocarbon process research, 1999. 13(2), 657 - 665.

14. Kerr, S., Richard, G. Evidence from U.S leadhase down. Journal of Industrial Economics, 2003. 33(4), $212-220$ 